\title{
Power, pork and patronage: Decentralisation and the politicisation of the development budget in Papua New Guinea
}

\section{Commonwealth Journal of Local Governance \\ Issue 6: July 2010 \\ http:/lepress.lib.uts.edu.au/ojs/index.php/cjlg}

\author{
Matthew Allen ${ }^{1}$ \\ Postdoctoral Fellow \\ Resource Management in Asia-Pacific \\ Program, Australian National University

\section{Zahid Hasnain} \\ Public Sector and Governance Specialist \\ The World Bank
}
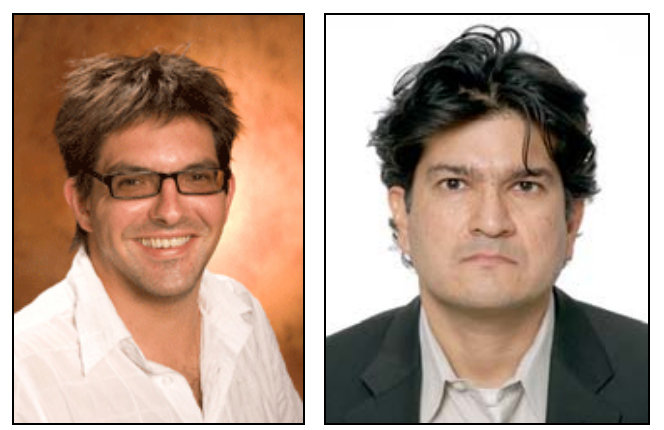

\begin{abstract}
This paper examines a number of recent empirical studies of local-level decision-making in relation to development planning and, especially, the allocation of state development funds in Papua New Guinea. The discussion is framed by the extensive theoretical and Papua New Guinea literature on patronage politics and political culture, by the recent history of decentralisation reforms, and by the frequently articulated, but largely anecdotal, observations about the functioning of district and local-level governance processes.In contrast to the anecdotal vision of widespread and chronic dysfunctionality, the studies considered here paint a picture of considerable spatial and regional variation. We offer some tentative hypotheses to explain this variation, while flagging the need for more empirical work. We outline how these preliminary findings have informed a program of research that is currently being undertaken at the district and local government levels with a view to gaining a better understanding of the extent and nature of spatial variation in the local-level governance of state development funds in Papua New Guinea.
\end{abstract}

\footnotetext{
${ }^{1}$ The authors would like thank two anonymous referees for their useful suggestions on an earlier draft. We also thank a number of colleagues at the ANU and the World Bank, too numerous to name here, for their advice and assistance during the preparation of the unpublished background paper upon which this article is based. We acknowledge the World Bank for funding this research. The opinions expressed herein remain our own.
} 


\section{Introduction}

In recent years, Papua New Guinea has been variously described as a 'failed state', a 'weak state', a 'broken-backed state', a 'fragile state', a 'putative state', and a 'disorderly democracy'. All of these terms have attempted to encapsulate the well-documented challenges of economic, political and social development that have confronted the largest of the postcolonial Melanesian nation-states. Indeed despite the recent commodity sector-led recovery from the macro-economic shocks and fiscal crises of the mid to late 1990s, the state has failed to convert resource revenues into development outcomes for the country's predominantly rural populace. Papua New Guinea continues to be the worst performing of all the Pacific Island states across a range of development indicators and spatial inequality is sharpening, not only between rural and urban areas, but also between different rural localities.

Why then, has Papua New Guinea performed so poorly over the three decades since independence - particularly in regard to basic social indicators and service delivery despite its fortunate resource endowment? While there is a large literature that emphasizes the predominance of patronage politics operating in an environment of extreme ethno-linguistic fragmentation as the underlying explanation for this failure, there have been relatively few empirical studies of local and district-level governance conducted to date that examine how a political culture of patronage is manifested at the local level. ${ }^{2}$ This paper analyses the small number of extant studies which have explicitly examined the issue of local-level decision-making around development planning and, especially, the allocation of state development funds. While the analysis is primarily situated in the Papua New Guinea-specific literature, linkages are also made to theoretical debates in comparative political economy.

In contrast to the anecdotal vision of widespread and chronic dysfunctionality, the studies examined here paint a picture of considerable geographical and regional variation in the functionality of district and local-level processes governing the allocation of development funds. While this variation invites explanation and hypothesis, most

\footnotetext{
${ }^{2}$ Papua New Guinea is the most fragmented of all the Melanesian states. Indeed, with approximately 820 languages and many more autonomous political units commonly described as tribes - around 10 thousand according to one informed estimate, many of which are further divided into clans (Ketan 2007:14) - it is the world's most fragmented society in ethno-linguistic terms. Some commentators have noted that a positive outcome of this fragmentation is that it has prevented collective action towards the overthrow of democratic rule and enabled PNG to be one of the few postcolonial states to maintain an unbroken record of democratic government.
} 
obviously in relation to corresponding variation in the prevalence and intensity of patronage politics, we argue that more work is required to better describe and understand the full spectrum of spatial variation before a rigorous explanatory framework can be proposed. Such work is currently being undertaken by the authors in conjunction with colleagues at the World Bank, the Australian National University and the Papua New Guinea Institute of National Affairs. This paper is offered as the first in an intended series of papers investigating local-level governance in Papua New Guinea, with a particular focus on decision-making processes around the allocation of state development funds.

The first part of the paper provides a brief overview of political culture in Papua New Guinea with an emphasis on the relationships between elections and patronage politics. Some regional variation is noted, in particular the general, but by no means immutable, distinction between the Highlands on the one hand, and coastal and island regions on the other. A number of salient linkages with the international theoretical literature are also examined. The second part of the paper examines several case studies of district and local-level governance derived from three separate research projects. The case studies are framed by an examination of frequently articulated, but largely anecdotal, observations about the functioning of district and local-level governance processes.

\section{Political culture, elections and patronage politics}

The introduced state and Westminster-style system of government have not replaced Papua New Guinea's pre-existing political structures and systems. The democratic state has hybridised with pre-existing political forms to produce syncretic political modes that exhibit elements of both Western and indigenous forms. Indeed, many would argue that the introduced state in Papua New Guinea has become thoroughly indigenised (Gordon and Meggitt 1985, Standish 1992, Ketan 1996, Morgan 2005).

Reviewing literature on the relationships between local political cultures and the formal state in Melanesia, much of which is concerned with Papua New Guinea, Morgan concludes that "pre-existing social forms pervade the state at almost every level" (Morgan 2005:4). For this reason, Morgan eschews political science's conventional preoccupation with the role of formal state institutions in governing political behaviour, in favour of an approach that places political culture at the centre of the analysis. He defines political culture as "the sets of actions and values that define and guide political 
behaviour”, a definition that is shared by several other scholars of Papua New Guinea (Morgan 2005:3; also see May 2004, Wolfers 1982, Ketan 2000 and Gelu 2000).

There is considerable support in the political science and anthropology literature on politics in Papua New Guinea for the proposition that patronage has become a critical defining characteristic of the postcolonial political system (May 1982; Standish 1992, 2007; Stewart and Strathern 1998; Goldman 2003; Ketan 2002; Ketan 2004; Morgan 2004). A number of scholars have directly linked the failure of governance with the ongoing prevalence of patronage, in addition to poor management and underlying capacity and skills constraints (see, for example, Ketan 2000, May 2004:323 and Morgan 2004:10). What, then, does this system of patronage look like, and what are the factors that drive it? These questions are now considered.

\section{The characteristics of patronage politics}

The literature indicates that patronage in Papua New Guinea is a two way interaction. This is clearly apparent if we consider the relationships between patronage and national elections. Candidates for political office spend increasingly large amounts of money on campaigning, which is distributed both as cash handouts and in the form of 'gifts' (Standish 1992, 1996, 2007; Strathern 1993; Stewart and Strathern 1998; Ketan 2000, 2004; Dinnen 2001). This is particularly the case in the Highlands where 'money politics' is more prevalent and where candidates have been known to spend up to a million kina during election campaigns (Ketan 2007:17; Standish 2007:140-142; Haley and Anere forthcoming:26). ${ }^{3}$ A candidate usually targets this expenditure on their own village, clan or tribal grouping, colloquially known as their 'voter stronghold' or 'vote bank’ (May 2006a).

Localism and clan mobilisation have been enduring features of national elections in Papua New Guinea (Hegarty 1983, Saffu 1996, Standish 2007), as has large numbers of candidates, meaning that seats have been won with very small proportions of the overall vote under the old first-past-the-post system (see Fraenkel 2004, 2005). Votes are effectively purchased by candidates - and this continues to be the case under the limited preferential voting (LPV) system first employed in a national election in 2007 - which

\footnotetext{
${ }^{3}$ Based on his close observation of elections in Papua New Guinea over a thirty year period, Standish notes that campaigning is generally more intense in the Highlands where clan groups are larger and more geographically concentrated, and where the numbers of candidates per electorate are much higher, often double, on average, the numbers campaigning in lowland areas (Standish 2007:140).
} 
creates one of the directional flows in the two-way patron-client interaction: the candidate 'pays' for the voting patronage of the constituent. The combined effect of clan mobilisation and large numbers of candidates is that MPs have been elected with very narrow popular mandates. They could be said to represent their primary kin group and, particularly in the Highlands, its alliance networks, at the expense of the wider electorate. The primary rationale behind the introduction of the LPV system was the hope that it would force candidates to campaign beyond their narrow strongholds, thereby broadening the representative base of elected MPs (Standish 2006, Reilly 2006).

It is important to note that the clan voting interpretation of electoral politics described above provides insufficient explanation for voting behaviour and electoral outcomes in all cases (Filer 1996, Saffu 1996, May 2006a, Standish 2007). Observers highlight important regional differences which have already been briefly noted above. The key distinction is between the Highlands on the one hand, and the lowlands and islands on the other. Generally speaking, in the Highlands clans are relatively larger, there are more candidates per electorate and, notwithstanding the increasing fracturing of the clan-based vote noted below, these candidates usually represent "clan-based voting blocks" (Reilly 1996:58; also see Saffu 1996, May 2006a and Standish 2007). In the coastal and islands regions, by contrast, "societies are comprised of much smaller clan and village units...and...candidates must mobilise numerous small social units, sometimes across several local vernacular languages” (Standish 2007:141).

The other directional flow in the patron-client relationship relates to the funding of electoral campaigns by constituents who understand that 'their' candidate, if successful, will repay and reward them with various forms of patronage including jobs, infrastructure, development projects and contracts (May 1997, Stewart and Strathern 1998). In this schema, the successful candidate is the patron and the constituent is the client. Moreover, even if supporters have not contributed to funding election campaigns, they nevertheless harbour a strong expectation of material gain and patronage in return for their votes (Hegarty 1983, Brown 1989, May 1997, Morgan 2004, McLeod 2008).

Of course, however, most candidates in national elections are not successful and this, coupled with the ever increasing numbers of candidates, has caused the fracturing of tribal, and even clan-based, votes in the Highlands, and the associated electoral and postelectoral violence that has increasingly characterised national elections across that region 
(Saffu 1996; Stewart and Strathern 1998; Rumsey 1999; Standish 2002, 2003, 2007; May 2003; Gibbs et al. 2004). Once in office, MPs will tend to use whatever resources they can access to repay their debts, reward their supporters and shore up support in their voter strongholds to ensure the best possible chance of re-election (May 1997, Stewart and Strathern 1998, Morgan 2004, Standish 2007). While all MPs have access to constituency development funds (see Ketan 2007), joining the Executive provides further opportunities to access resources for distribution, and becoming a minister affords the best possible opportunities of all (Morgan 2004:4).

This depiction of the characteristics of patronage politics in Papua New Guinea is in line with a number of general conclusions from the more theoretical political science and economics literature that has examined elected policy-makers' incentives for providing public goods and improving service delivery. A stylised fact that has emerged in the literature is that policies in developing-country democracies generally benefit narrow interests at the expense of broad social interests. The older public choice literature (Olson 1965, Bates 1981) focused on how the greater organizational ability of special interest groups led to policy failures, such as destructive agricultural policies in Africa. However, this literature's emphasis on organized interest fails to explain why some democracies are more vulnerable to special interests than others.

The strands of the more recent political economy literature that are particularly relevant to Papua New Guinea explain under-investment in public goods and a predominance of patronage as a result of either a) politicians discounting the future too much; and/or b) the electoral benefits from the pubic goods not being internalized by them or, in other words, political market failures. On the former, as Olson (1993) noted, politicaleconomic settings characterized by systemic instability and a high degree of political contestation and turnover are akin to 'roving bandits', and, since politicians have a short time horizon, they have an incentive to 'loot today' rather than to 'invest for tomorrow'. On the latter, politicians will have an incentive to provide targeted benefits to their supporters in situations where they will not receive electoral benefits from providing public goods due to the difficulty involved in mobilising support for public goods across ethnic groups (Easterly and Levine 1997, Alesina et al. 1999, Alesina and La Ferrara 2005, Keefer 2010); the lack of credibility of national political organizations for providing these goods (Keefer 2007); or voters' lack of information about the actions of individual politicians (Besley 2006). 
It is worth spelling out how this literature would explain the failure of public good provision and the predominance of patronage politics in Papua New Guinea. Extreme social fragmentation manifest in large numbers of candidates means that each elected policy-maker has a very limited time horizon and is unlikely to be able to generate sufficient political support from clans other than his own by providing public goods to them. Moreover, the lack of voter information means that even if clan identity was not a primary form of political mobilization, voters would be unable to associate a good outcome with the actions of a particular politician, further increasing the incentive to provide targeted benefits for which credit can more easily be claimed. Underdevelopment of political parties means that politicians cannot coordinate to achieve national goals or appeal to voters through partisan platforms, and instead must build personal relationships based on providing individual favours.

A further implication of this literature is that once elections are incapable of enforcing accountability then the type of politicians seeking office will also change: honest competent individuals will be discouraged from seeking office and instead candidates who are more inclined towards 'money politics', will take over the political arena (Besley 2006).

A detailed description of the drivers of patronage politics is not possible here. Suffice to say that a survey of the literature points to a number of factors that have combined to give rise to a postcolonial political culture in Papua New Guinea that is strongly characterised by localism and patronage. The interrelated issues of extreme social fragmentation, the lack of commitment to abstract notions of state and nation, traditional leadership styles, wantokism, aspects of the colonial legacy, the collapse of state services and the non-emergence of strong political parties have all contributed to the prevalence of patronage politics in contemporary Papua New Guinea. Above all, however, it is the expectations of citizens themselves which have determined the boundaries of acceptable political behaviour (especially see May 1997; Ketan 2004, 2007; Morgan 2005; and McLeod 2008),

\section{Decentralisation and the politicisation of the development budget}

The avowed spirit and intention of the 1995 Organic Law on Provincial Governments and Local Level Governments (OLPGLLG) was to 'bring government closer to the 
people', particularly with regard to access to government services. However, the final form of the Organic Law, in concert with subsequent amendments, has produced deeply contradictory outcomes. Rather than strengthening the role of LLGs in decision-making around service delivery issues, LLGs have been increasingly marginalised from planning and financial decision-making processes at both provincial and district levels. They have also been starved of funding to perform their basic planning and service delivery functions (Barter 2004; May 2006b; National Economic and Fiscal Commission 2007; Gelu 2009, forthcoming). The 89 open electorate MPs and their associated electoral and administrative units - the districts - have eclipsed or overshadowed all other forms of local political activity. Indeed the OLPGLLG and subsequent amendments thereto can be interpreted as a successful attempt by national level politicians, particularly Open MPs, ${ }^{4}$ firstly to remove their competitors in the form of elected provincial representatives, and then to gradually increase the volume of resources directly channelled into the district level over which they have developed significant de facto and de jure control. Many observers would agree with Ron May's assessment that the "real objective" of the 1995 Organic Law was "to substantially increase the political role of national MPs” (May 2004:202).

LLGs are defined under the OLPGLLG as elective bodies that represent communities. They can take a wide variety of different forms from urban authorities or councils through to traditional governmental structures. Most of their membership is comprised of elected councillors representing the wards in the LLG area. The law distinguishes between urban and rural LLGs for the purposes of funding and appointed membership (see Kalinoe 2009:16). The president of the LLG can either be elected by all of the people in the LLG area, as is often the case in the lowlands; or by a vote of the LLG councillors, which is more commonly the case in the Highlands (May 2005b:2).

LLGs have a large range of functions including: preparing rolling five year plans taking account of the equivalent ward plans; preparing annual plans and budgets based on the five year plan; constructing and maintaining infrastructure; and facilitating renewable natural resource development (Kalinoe 2009:17). LLGs were also given significant legislative powers under the OLPGLLG, covering matters such as labour and employment, self-help schools, dispute settlement, local environment and local aid posts (May 2004:198). The number of LLGs and wards has increased since the introduction of

\footnotetext{
4 There are 109 seats in the National Parliament. Twenty of these are Regional seats, sometimes referred to as Provincial seats, one for each of the 19 Provinces and the National Capital District. The remaining 89 seats, known as Open seats, are co-terminous with District boundaries.
} 
the Organic Law in 1995. There are currently somewhere between 303 and 313 LLGs and 6,003 and 6,137 wards in Papua New Guinea (Anere 2008; Gelu forthcoming).

The OLPGLLG mandated six types of grants to provinces and LLGs to supplement their internal revenue sources (principally head tax, fees and fines, petroleum and mining royalties and dividends) and the payment of proceeds from certain tax revenues collected by the national government (a share of GST). There have been a number of widely recognised problems associated with the inter-governmental financial arrangements introduced under the 1995 Organic Law. Many of these stemmed from the effective "delinking of funding and function” which occurred with the introduction of a system for determining the value of provincial grants based on a formula rather than on the actual cost of delivering services (National Economic and Fiscal Commission 2003:15). These problems associated with fiscal equalisation have recently been addressed through reforms to the inter-governmental fiscal transfer regime. ${ }^{5}$ However, while these reforms hold considerable potential for solving some of the administrative and financial dysfunctions of the previous system, they will have no effect on the allocation and administration of grants allocated under the development budget.

These development grants are under the discretion of the Joint District Planning and Budget Priority Committees (JDPBPCs) which, since their establishment by an amendment to the OLPGLLG in 1996, have been responsible for overseeing all aspects of planning, prioritisation and budgetary considerations at the district level. In addition to the MP representing the district as chair, each JDPBPC consists of the heads of the LLGs in the district and up to three other members appointed by the MP in consultation with the heads of the LLGs. The District Administrator (DA) is the chief executive officer of the JDPBPC. These committees are also responsible for the administration of the fifty percent of each MP's District Support Grant that is non-discretionary (Ketan 2007) and for a range of other grants that flow directly to the district level via the national Office of Rural Development, including the recently ramped up District Services Improvement Program (DSIP).The politicisation and unaccountability of these committees in many, though importantly not all, parts of the country has been widely commented on (if not

\footnotetext{
${ }^{5}$ For details of these reforms see National Economic and Fiscal Commission (2009) and Gouy (2009). In short, the new 'fiscal equalisation' regime introduced via amendments to the OLPGLLG and the enactment of the Intergovernmental Relations (Functions and Funding) Act 2009 specifically addresses the issue of horizontal imbalances in fiscal capacity. Grants for provinces and LLGs will now be determined according to their 'fiscal needs amount'. This will be calculated for each province and LLG by subtracting its assessed revenues from its estimated costs of service delivery.
} 
particularly well documented), leading to recommendations for their immediate abolition in two separate recent official reviews (Public Sector Reform Advisory Group 2006, Department of Provincial and Local Government Affairs 2007).

The process that was set in train by the 1995 'decentralisation' reform is on-going and has recently been described by one informed commentator as "a kind of decentralisation race to the bottom" (Whimp 2009:3). This race has been characterised by the progressive increase in resources being channelled into the district level and the concomitant adoption of both legislative and de facto measures to increase the control that Open MPs have over such resources. Hence we have seen, since the original enactment of the OLPGLLG in 1995, amendments to it which have: established the JDPBPCs and with them District and Provincial Support Grants; removed the Regional MPs from the JDPBPCs; and, most recently, removed LLG presidents from provincial assemblies arguably providing Open MPs with more power and leverage vis a vis provincial governors. ${ }^{6}$ Alongside these developments was the increase in District Support Grants, but not Provincial Support Grants, to a maximum of K1.5 million for each Open MP in 1999 (though we must also note the bearing that the machinations of parliamentary politics have had on the capricious nature of these allocations); and, most recently, the dramatic increase in the District Services Improvement Program (DSIP), which was introduced in the National Budget as a non-constitutional grant, ${ }^{7}$ to K4 million, K6 million and K4 million per district in the 2007, 2008 and 2009 appropriations.

De facto arrangements have been centred around the deliberate marginalisation of LLG presidents, and even District Administrators, from JDPBPC decision-making processes, meaning that the significant amount of funds now being channelled through the districts can be, and are being, used for pork-barrel politics. This comes at the significant cost of

${ }^{6}$ It appears that the rationale behind the November 2006 amendments to the OLPGLLG which removed LLG presidents from provincial assemblies was that they would instead sit on new bodies which were to be called District Authorities. A bill to establish such authorities was introduced by then Leader of the Opposition Peter O’Neil in 2006. The District Authorities Bill was passed, but has never been gazetted, apparently because the Minister did not sign off on it (National Research Institute 2008:60-61).

Subsequent moves to enact legislation to reinstate LLG presidents to provincial assemblies appear to have foundered. One possible interpretation is that it is not in the interests of Open MPs, who dominate parliament and exclusively constitute the National Executive Council (cabinet), to have LLG presidents reinstated. Note that the Supreme Court has recently ruled the 2006 amendment to be unconstitutional, which would appear to pave the way for LLG presidents to be reinstated to Provincial Assemblies (The National, 7 June, 2010).

${ }^{7}$ Constitutional grants are mandated under OLPGLLG. They are the District and Provincial Support Grants. Non-constitutional grants are allocated in the development budget as part of the Public Investment Program (PIP). The DSIP is administered at the national level by the Office of Rural Development. Decisions about how the funding is allocated are made at the district level by the JDPBPC (Sai'i 2008; also see Government of Papua New Guinea, n.d.). 
good service delivery outcomes not only because projects are targeted at MPs' voter strongholds at the expense of the wider electorate, but also because there is a strong emphasis on capital investments made with scant regard to provincial, district, LLG or ward planning processes and, therefore, to on-going operational funding. Peter Barter describes this situation as follows:

In many instances, parliamentarians select projects and disburse funds without consultation and cooperation from district officers or LLGs. Funds are often allocated with dubious justification to businesses belonging to individual families. In other instances, LLGs are saddled with maintenance responsibilities for such projects as water supply systems for which they are not prepared - because they were constructed by parliamentarians with direct-tied grants, but without the required consultations and feasibility studies (Barter 2004:140-141).

Barter continues:

The system bypasses the provincial and local-level planning systems, and downgrades the elected LLGs and district public service. The Joint District Planning and Budget Priorities Committees do not function. In turn, LLG presidents become isolated from their councillors because they tend to rubber stamp the National Members' political wishes (Barter 2004:141).

This view of the JDPBPCs is one which is shared by the Public Sector Reform Advisory Group (2006) and the Department of Provincial and Local Government Affairs (2007), both of which have recommended their abolition in recent review reports. According to the former review:

The structure of the membership enables MPs who represent the open electorates to largely control the budget allocation, and override heads of LLGs. They are ex-officio members of JDPBPCs. Many chairpersons dominate their JDPBPCs, with meetings held irregularly, and sometimes outside the district. It weakens the LLGs role to have a politically constituted committee that neither belongs to, nor answers to any level of government, that makes decisions on budgeting and planning for LLGs (Public Sector Reform Advisory Group 2006:31).

Ketan offers the important observation that another way in which MPs can control the decisions of JDPBPCs is through their control over the individual members of the committees. Ketan states:

Administrators and community leaders who sit on planning and budget priorities committees are often in client-patron relations with the MPs, thereby enabling the MP to exert considerable influence over them.

(Ketan 2007:20)

Ironically, the main argument made in favour of electoral development funds and other grants over which MPs have significant control (such as the DSIP) is the deterioration of 
service delivery, particularly in rural areas. Ketan provides a detailed discussion of the arguments made for and against such funding programs (2007:8-14). Supporters of the funds argue that they were initially devised as a useful way of capitalising on MPs' intimate knowledge of their electorates and bypassing bureaucratic bottlenecks to fund critical infrastructure projects to the benefit of the whole electorate.

The reality is that service delivery has deteriorated to varying extents across the country, leading to a "widespread feeling that the 1995 reforms have not solved the problems of the decentralised system” (May 2006b:9). According to the government’s Medium Term Development Strategy (2004):

...in the years since the passage of the Organic Law [1995], service
delivery has deteriorated. On the whole service delivery systems are
dysfunctional and there remains widespread confusion over functional
(who does what) and financial (who pays for what) responsibilities
across the three levels of government. As well, institutional capacity to
deliver services is at best described as grossly inadequate (Medium
Term Development Strategy cited in May 2006b:9).

Importantly, Ketan provides a handful of examples of MPs who have used their funds responsibly, by allowing funding applications to be properly screened by committees and by using the accounting mechanisms of provincial governments to comply with financial management guidelines (Ketan 2007:29-31). However, before moving on to examine some recent case studies of district level governance, it is important to note Ketan's conclusion that such positive stories comprise the minority of cases. Moreover, three of the MPs in question lost their seats in subsequent elections, demonstrating that good management of electorate development funds provides no guarantee of continued electoral success.

The above-noted marginalization of LLGs highlights the important role played by national-level parliamentary politics in driving political dynamics at the lower levels of government. An important change in national-level political dynamics brought about by the OLPGLLG has been the dominance of the composition of cabinet, known as the National Executive Council (NEC), by Open MPs. This is because the OLPGLLG stipulates that the Regional MP will normally become Governor of the Province unless he or she accepts any national responsibility as a Minister or head of a Parliamentary Committee (or becomes Leader or Deputy Leader of the Opposition). Most Regional Members have opted to become Provincial Governors, thereby leaving cabinet positions to the Open MPs. The control of national-level executive decision-making by MPs who 
have a strong vested interest in increasing the concentration of resources and power at the district level (as well as their significant numerical supremacy in parliament as a whole) has arguably informed a succession of decisions and amendments which have progressively increased the size of Open MPs 'slush funds' and their level of control over them and other types of grants that are administered by the JDPBPCs (Whimp 2009). ${ }^{8}$

This marginalization of LLGs also extends to administrative authorities. The OLPGLLG effectively abolished provincial public services and removed the power of provincial governments and LLGs to employ staff. These provisions have caused significant confusion primarily because it is not clear how the provincial-level reporting structures and the authority of the Provincial Administrator relate to the "chain of command within national departments and agencies” (May 2004:197). The provisions also raise issues concerning the accountability of senior provincial staff to their political leadership given that the latter have no say in their hiring and firing.

\section{Recent case studies of district and local-level governance}

As mentioned previously, there is a paucity of recent published research and analysis of the interactions between the lower levels of government and administrative units in terms of development planning and financial decision-making. This sub-section draws upon the preliminary findings and reports of two recent research exercises to examine case studies of these interactions in districts drawn from several different parts of the country. One of the projects was undertaken by the State, Society and Governance in Melanesia (SSGM) program in conjunction with researchers from Divine Word University and the NRI (Haley 2005; May 2005a, 2005b); and the other by the Constitutional and Law Reform Commission (CLRC) (Kalinoe 2009, CLRC 2009 ${ }^{9}$ ). A third relevant research exercise is the district and LLG profiling work being conducted by NRI (Gelu 2009, Gelu forthcoming). This research is on-going and has not thus far reported sufficient data to

\footnotetext{
${ }^{8}$ See Ketan for a detailed discussion of electoral development funds in Papua New Guinea. Their value increased from K100,000 in 1993 to K300,000 in 1994 and K550,000 in 1996. In a development that exemplifies the point being made here, while the Provincial Support Grants to Regional MPs remained at K500,000 each, the Open MPs' allocations in the form of District Support Grants rose to K1.5 million each in 1999, before being reduced back to K500,000 in the face of "public outcry" (Ketan 2007:7). Ketan also observes that governments have used electoral development grants to maintain power by placating government backbenchers who threaten to cross the floor and 'punishing' opposition MPs (2007:7, 10).

9 This work is based on surveys in six provinces: New Ireland, Morobe, Eastern Highlands, Southern Highlands, East Sepik and Gulf.
} 
support detailed case studies here. However, the general findings of this exercise reported to date, which relate only to the Southern Region, are briefly considered.

The districts that are examined in detail are: Kavieng in New Ireland Province (Kalinoe 2009, CLRC 2009); Madang in Madang Province (May 2005a); Goroka, Unggai-Bena and Daulo in Eastern Highlands Province (May 2005a, CLRC 2009); Rabaul and Kokopo in East New Britain District (May 2005a); and Mendi and Koroba-Lake Kopiago in South Highlands Province (Haley 2005, May 2005a, CLRC 2009). The two research exercises in question employed broadly similar methodologies, primarily consisting of the collection of qualitative data through semi-structured interviews with a range of stakeholders (politicians, civil servants and civil society representatives) in each location. However, it is important to note that the research conducted by May et al. explicitly considered a wider range of issues than that undertaken by CLRC. The data reported in the surveys conducted by May et al. are current as at late 2004/early 2005, and that reported by CLRC are current as at 2008/2009.

These case studies demonstrate the considerable variation in the functionality of local level planning processes, from the relative good performance and inclusiveness of local, district and provincial level planning and funding processes in East New Britain Province, to the dysfunctional 'worst-case scenario' of Southern Highlands Province and New Ireland Province. In East New Britain, for example, the Rabaul and Kokopo JDPBPCs meet frequently and are said to be effective. In both districts, there is reportedly close collaboration between the Open MPs, the JDPBPCs and the district administrations, and seemingly effective involvement of civil society. By contrast, in Southern Highlands the Mendi and Koroba-Lake Kopiago it is reported that JDPBPCs do not meet, there is no involvement of the community, LLGs, or district staff in the utilization of the DSIP and other funds, and the discretion of the MP appears to be complete.

\section{Madang Province: Madang District}

The past three Open MPs had all come from outside the province and one respondent suggested that a "local Madang man would have real problems". The Open MP at the time of the survey was an Engan who lived and maintained his office in Port Moresby. The DA at the time was from Manus Province. The JDPBPC had met only once during 2004 and the DA did not attend the meeting. The Open MP was accused of "stacking" 
the JDPBPC. The district five year plan was said to have lapsed and interviewers were told that "politicians don’t really respect the public servants".

\section{Eastern Highlands Province: Goroka, Unggai-Bena and Daulo districts}

Respondents reported a general apathy towards the government and politicians, with the exception of the Regional MP at the time who was said to have been doing a good job. District administration was described as satisfactory, though at least one DA lived outside of the district. Relations between district and provincial administrations were also described as satisfactory. The functioning of JDPBPCs was variable in terms of the frequency and location of meetings, with reports that some meetings were held in Port Moresby. Civil society was said to be adequately represented on JBPBPCs. Most districts appeared to have five year plans, but rolling plans were described as "under review" or "yet to be finalised". It was reported that many wards did not have plans, more so in the less developed districts.

Although there is legislative provision in the province for LLGs to collect head taxes, they do not do so, meaning their primary source of internal revenue is from village court fines, trade store licenses and market fees. However people are often unwilling to pay these due to widespread distrust of the government and accusations of misappropriation of funds at both the ward and LLG levels. There were also reports of councillors "abusing their powers" and a former provincial premier said that LLG presidents are often young educated men who do not understand the realities of village life.

Several respondents claimed that service delivery was poor, particularly in the more remote districts, but that civil society was "filling the gaps". Major communications and transport constraints were reported in all districts. Public servants in Daulo and UnggaiBena reported difficulties accessing their pay due to the lack of banking services in those districts.

\section{Southern Highlands Province: Mendi and Koroba-Lake Kopiago districts}

Both districts were without Open MPs at the time of the survey (in the case of Mendi the MP had been removed from office after being found guilty of misappropriating funds; and in Koroba-Lake Kopiago the MP had been removed following a technical appeal against the 2002 election result). In Mendi, relations between the district and provincial administrations were described as "poor". The DA was frequently absent and the 
JDPBPC met infrequently, usually in Port Moresby or Goroka. In the absence of the Open MP, the JDPBPC was said to be controlled by associates of the provincial governor.

In Koroba-Lake Kopiago, the DA was also said to be frequently absent from the district. While relations between the district and provincial administration were said to be satisfactory, it was claimed that successive DAs had been political appointments. The JDPBPC was said to meet only once or twice a year and even then outside the district in Port Moresby or Goroka. One informant stated that LLG presidents had been given money to go off and "drink and play the pokies” while the meeting was in progress. It was also reported that civil society is not involved in the JDPBPC process. In both districts it was said that LLG presidents and councillors had been politically appointed by the provincial government and that this, in conjunction with lack of funds, had undermined the LLG system. In both districts there was uncertainty as to the existence of district plans and the planning process was said to be highly politicised.

In terms of revenue and expenditures, there were reports in both districts of widespread misuse of funds and of MPs using funds to buy support. LLGs do not collect head taxes. Koroba-Lake Kopiago is without banking services and public servants travel by air transport to Mount Hagen to collect their pay and, according to one respondent, they "often get stuck there for months at a time". Service delivery was said to be unsatisfactory in both districts. The poor security situation is a significant impediment to service delivery in these areas due to frequent road blocks and the widespread breakdown in law and order.

\section{East New Britain Province: Rabaul and Kokopo districts}

Respondents in both districts said that the Open MPs had served the districts well. In both cases the JDPBPCs had met several times during 2004 (six times in the case of Rabaul and three in the case of Kokopo) and were said to be effective. There was said to be close collaboration between the Open MP, the JDPBPC and the district administration in both districts. Civil society is represented on both JDPBPCs by women's, youth and churches' representatives; and civil society (including NGOs, business and village communities) is said to play an important role in development at both district and provincial levels. 
All districts in the province have five year plans. In both Rabaul and Kokopo, ward development plans were said to be feeding into the LLG and district planning processes. Both provincial sectoral staff and civil society groups actively participate in planning at the ward level, and LLG presidents submit their LLG plans to the JDPBPC. District plans contain summaries of all the LLG plans. The Rabaul DA reported that funding was sometimes late or inadequate, but that coordination between government agencies in the district was generally satisfactory. The relationships between LLGs and district administrations was said to be "very good". In both districts it was reported that Open MPs have generally allowed JDPBPCs to allocate their District Support Grants. Head taxes have been introduced at the LLG level and in Kokopo revenue from these taxes is shared between the ward and the LLG. In Rabaul it was reported that communities contribute in kind to local projects, for example, by providing carpenters to help build a classroom initiated by the JDPBPC. In both districts access to basic services was said to be good, though some respondents said that service delivery had been politicised. Other obstacles to service delivery included inadequate funding, manpower shortages, poor management skills and logistical constraints.

\section{New Ireland Province: Kavieng District}

From 2002 to 2007, and under the initiative of the former governor, a parallel and unregulated system was established for distributing provincial funds to constituents that resulted in a considerable deterioration of service delivery in the province. This parallel system, known as the Limus Structure, was essentially the use of the governor's 2002 election campaign committees as a vehicle for distributing state resources, entirely bypassing the provincial government, district administrations, and local level governments. As a result, there were no budgetary provisions to line departments, and a complete lack of functionality of the established provincial and district administrations.

In Kavieng, the DA, who had been in the position for around two years, stated that the lack of office and housing infrastructure, particularly at the rural LLG sub-districts, was a major constraint to the provision of services because field staff were based in town. Even in the case of Kavieng District headquarters, which is located in town, there is no designated district administrative office, meaning that district staff are scattered around different parts of town. 
The DA also stated that district and LLG grants mandated under the OLPLLG were often late in arriving and were not in accordance with the prescribed funding formula. The small amount of funding received by LLGs, usually late in the year, is only sufficient to pay councillors allowances. The Kavieng Town Mayor (who is the elected head of the LLG) and the Town Manager similarly stated that lack of funding was a serious constraint. They had not received any funding from the provincial government for the past four years and had been entirely dependent on national government grants.

With regard to the Kavieng JDPBPC, the DA stated that it had not been functioning effectively for the past four years. On two instances the JDPBPC had met without the knowledge or involvement of the DA.

\section{Southern Region: preliminary findings from LLG and district profiling}

The findings from this survey have thus far only been reported in summary form in an National Research Institute Spotlight publication (Gelu 2009) and, to a lesser extent, in an unpublished conference paper (Gelu forthcoming). The survey collects questionnaire data from district and LLG officers, and records the assets and facilities of districts and LLGs. To date the survey has only been conducted in the Southern Region (Western, Gulf, Central, Oro and Milne Bay provinces). In the case of the districts surveyed (Rigo, Kairuku, Alotau, Tufi, Kerema and North Fly), the following observations have been reported in relation to development planning, funding issues and service provision:

- Inadequate funding is a problem in all districts.

- There is unclear delineation of authority between districts and provincial administrations, particularly in Tufi and Kerema.

- JDPBPCs are ineffective due to lack of transparency and irregular meetings, particularly in Kairuku, Tufi and Kerema.

- There was a lack of awareness in all districts about the DSIP and how the funds were being used.

- Tufi and Kerema do not have district plans.

- All districts experience varying degrees of administrative constraints relating to staffing, infrastructure and transport.

- All districts have problems with health and education services including lack of staff, materials and supplies. Church-run schools and health centres generally have better facilities, supplies and material than government-run services. 
The following relevant observations have been reported in relation to the LLGs profiled (Rigo Central Rural, Mekeo/Kuni Rural, Huhu Rural, Alotau Urban, Kerema Central, Kiunga Rural, and Tufi Rural):

- None of the LLGs have either LLG or ward development plans;

- Only two LLGs receive sufficient funding to support administration and service delivery. These are Huhu Rural LLG, which raises revenue in the form of fees from Alotau market; and Kiunga Rural LLG, which receive royalties from Ok Tedi mine;

- The LLGs generally lack administrative capacity and some lack council chambers.

The case studies presented above lend significant weight to the generalised and frequently cited observations about district and local-level governance that were examined in the previous sub-section. This particularly applies to the domineering role that many Open MPs play in development planning and financial decision-making at the district level, to the exclusion of LLG presidents, ward councillors, and communities and civil society at large. However, the case studies also provide a window into the enormous diversity and variation in practice that exists across the country. This diversity of planning and financial decision-making contexts is directly reflected in the range of service delivery outcomes that are observed in different provinces and districts. . Again, we can point to East New Britain and Southern Highlands as exemplars of good and bad service delivery outcomes respectively. Most local-level contexts in Papua New Guinea probably lie somewhere along the continuum between the case study districts examined in these two provinces.

\section{Conclusion}

As stated in the introduction, empirical field data on the functionality and inclusiveness of district and local-level decision-making around development planning and, particularly, the allocation of state development funds is too inchoate to be able to start developing rigorous frameworks to explain apparent variation. That said, the finding of significant spatial variation is in itself important as it challenges the orthodoxy that these local-level processes are ubiquitously dysfunctional and the associated assumption that all development funds, so-called slush funds, are being used for pork-barrelling in MPs' voter strongholds. Moreover, the apparent extent of spatial variation lends itself to the development of hypotheses to explain this variation. One tentative hypothesis is 
canvassed below. However, more work is clearly required to gain a better understanding of the extent and nature of spatial variation in the local-level governance of state development funds. As mentioned at the outset, a program of research is currently being undertaken at the district and LLG level with a view to doing precisely this.

The bare bones provided by the case studies sketched out here, and the accompanying survey of the literature on political culture and patronage, has enabled us to frame this research program around some of the relationships that appear to emerge from the limited data available to date. The spatial variation in the extent to which MPs marginalise LLG presidents in order to control the allocation of development funds appears to loosely map onto similar patterns of spatial variation in the intensity of patronage politics, money politics, and the traditional and on-going importance of the 'big-man' system. ${ }^{10}$ The critical, though by no means immutable, distinction is between the Highlands on the one hand, and the lowlands and islands on the other; with the former characterised by clan-voting and more aggressive and individualistic leadership styles, and the latter by a greater emphasis on mediation and group decision-making. This provides an initial hypothesis: that functionality is related to the intensity of patronage politics. Importantly, however, the evidence of relative dysfunctionality in parts of some coastal and island provinces, such as Madang and New Ireland respectively, highlights the clumsiness and crudeness of this geographical dichotomy. Data from a larger number of districts and LLG areas will enable us to investigate these spatial relationships more rigorously, and the field sites have been selected accordingly.

Another important research question relates to the impact of limited preferential voting (LPV). The change in the electoral system has raised the potential for significantly changing the clan, tribal and patron-client dynamics associated with elections, and therefore local resource allocation. The introduction of LPV was an attempt at electoral engineering in the sense that it was "intended to change people's electoral behaviour or political culture, and in particular to break down the intense localism found in most areas of Papua New Guinea” (Standish 2006:197). Importantly, the preliminary evidence relating to the impact of LPV on campaigning in the 2007 election indicates that while

\footnotetext{
10 The behaviour of politicians in contemporary Papua New Guinea strongly resonates with the leadership style of traditional big-men. Notwithstanding important regional variations, a key defining characteristic of traditional big-man politics is the accumulation and distribution of resources to create webs of obligation and reciprocity; or, in other words, patron-client relations. It is this particular aspect of the big-man model that finds most resonance in the 'tactics' and behaviour of modern Melanesian parliamentarians (see Morgan 2005 and McLeod 2008).
} 
candidates sought votes and preferences more widely than they have done in the past, the basic pattern of campaigning has remained the same (Haley and Anere forthcoming; also see May 2008). Moreover money politics intensified in the 2007 election, possibly as a consequence of the increased scope for vote buying under the LPV system.

However, one area for cautious optimism relates to campaigning strategies around the allocation of preferences (Standish 2006, May 2008, Haley and Anere forthcoming). There is evidence to suggest that in five of the ten districts which had previously had a LPV by-election, voters during the 2007 election allocated preferences to strong candidates with solid track records. This is a promising departure from the widespread strategy observed during the 2007 election and in previous LPV by-elections whereby candidates asked their primary voters to direct their preferences to minor candidates who were unlikely to pose a threat. The selection of districts in our current research program will enable us to investigate possible relationships between LPV and patronage politics.

\section{References}

Alesina, A. and La Ferrara, E. 2005. 'Ethnic Diversity and Economic Performance’, Journal of Economic Literature, XLIII:762-800.

Alesina, A, Baqir, R. and Easterly, W. 1999. 'Public Goods and Ethnic Divisions', Quarterly Journal of Economics, 119(2):565-611.

Anere, R. 2008. Local Government and the Evolution of Local Democracy in Papua New Guinea, 1964-2008. Spotlight with NRI, 2(2). The National Research Institute, Port Moresby.

Besley, T. 2006. Principled Agents?The Political Economy of Good Government. Oxford: Oxford University Press.

Barter, P. 2004. 'Blunt assessments, hope and direction: lower level governments in Papua New Guinea’, in N. Sullivan (ed.), Governance Challenges for PNG and the Pacific Islands. Madang: Divine Word University Press.

Bates, R. 1981. Markets and States in Tropical Africa: The Political Basis of Agricultural Policies. Berkeley: University of California Press.

Brown, P. 1989. 'The Simbu Election’,in M.Oliver (ed.), Eleksin: The 1987 National Election in Papua New Guinea. Port Moresby: University of Papua New Guinea.

Constitutional and Law Reform Commission (CLRC) 2009. Review of the Implementation of the OLPG\&LLG on Service Delivery Arrangements: A Six Province Study. Port Moresby: Constitutional and Law Reform Committee.

Department of Provincial and Local Government Affairs 2007. 'Review of the Organic Law on Provincial Governments and Local Level Governments', Port Moresby: Department of Provincial and Local Government Affairs.

Dinnen, S. 2001. Law and Order in a Weak State: Crime and Politics in Papua New Guinea. Honolulu: University of Hawai'i Press.

Easterly, W. and Levine, R. 1997. 'Africa’s Growth Tragedy: Policies and Ethnic Divisions', Quarterly Journal of Economics, 112(4):1203-1250. 
Filer, C. 1996. 'Steak and Grease: A Short History of Political Competition in Nuku', in Y. Saffu (ed.) The 1992 PNG Election: Change and Continuity in Electoral Politics. Canberra: Department of Political and Social Change, Research School of Pacific and Asian Studies, The Australian National University.

Fraenkel, J. 2004. 'Electoral engineering in Papua New Guinea: Lessons from Fiji and elsewhere', Pacific Economic Bulletin, 19(1):122-133.

Fraenkel, J. 2005. Political Consequences of Pacific Island Electoral Laws. State Society and Governance in Melanesia.Discussion Paper 2005/8. Canberra: Research School of Pacific and Asian Studies, The Australian National University.

Gelu, A.R.M. 2000. 'The Emergence of Non-Liberal Democratic Political Culture in Papua New Guinea’, in M.A. Rynkiewich and R. Seib (eds), Politics in Papua New Guinea: Continuities, Changes and Challenges. Goroka: The Melanesia Institute.

Gelu, A. 2009. Profiling local-level governments and districts in Papua New Guinea. Spotlight with NRI, 3(2). The National Research Institute, Port Moresby.

Gelu, A. (Forthcoming). 'LLGs and the System of Governance: The East New Britain Case Study on Devolution', in R. Eves (ed.), Governance at the local level: Melanesians Responding to Governance Issues, State Society and Governance in Melanesia Program, The Australian National University.

Gibbs, P., Haley, N. and McLeod, A. 2004. Politicking and Voting in the Highlands: The 2002 Papua New Guinea National Elections, State Society and Governance in Melanesia Discussion Paper 2004/1. Canberra: Research School of Pacific and Asian Studies, The Australian National University.

Goldman, L. 2003. 'Hoo-Ha in Huli': Considerations on Commotion and Community in the Southern Highlands Province of Papua New Guinea, State Society and Governance in Melanesia Discussion Paper 2003/8, Canberra: Research School of Pacific and Asian Studies, The Australian National University.

Gordon, R., and Meggitt, M. 1985. Law and Order in the New Guinea Highlands. Hanover: University Press New England.

Gouy, J. 2009. 'Papua New Guinea’s intergovernmental financing reforms: An assessment',Pacific Economic Bulletin, 24(1):113-129.

Government of Papua New Guinea n.d. 'Framework for Administration and Accountability of District Services Improvement Program’, Port Moresby: Government of Papua New Guinea.

Government of Papua New Guinea 2006. 2006 National Budget. Volume I. Port Moresby: Government of Papua New Guinea.

Government of Papua New Guinea 2008. Final Budget Outcome 2007. Port Moresby: Government of Papua New Guinea.

Government of Papua New Guinea. 2009a. Final Budget Outcome 2008. Port Moresby: Government of Papua New Guinea.

Government of Papua New Guinea 2009b. National Budget. Volume III. Port Moresby: Government of Papua New Guinea.

Haley, N. 2005. 'District Government - Information Collection Southern Highlands Province', 20 April 2005.

<http://rspas.anu.edu.au/papers/melanesia/conference_papers/0506_PNGDistrictGovernan ce_SHP_infocollection.pdf $>$ Accessed 15 May 2009.

Haley, N. and Anere, R. (Forthcoming). Election 2007 Domestic Observation: Final Report, National Research Institute and The Australian National University. 
Hegarty, D. 1983. 'The 1977 national elections in Papua New Guinea: An overview'in D. Hegarty (ed.), Electoral Politics in Papua New Guinea: Studies on the 1977 national elections. Port Moresby: University of Papua New Guinea.

Kalinoe, L. 2009. A Review of the OLPLLG: The New Ireland Provincial Government Experience 2002 - 2007, unpublished paper presented in the State, Society and Governance in Melanesia Seminar Series at The Australian National University, Canberra, December 2008.

Keefer, P. 2007. 'Clientelism, Credibility, and the Policy Choices of Young Democracies', American Journal of Political Science, 51(4):804-821.

Keefer, P. 2010. 'The Ethnicity Distraction: Political Credibility and Partisan Preferences in Africa', Policy Research Working Paper Series, 5236. The World Bank.

Keesing, R.M. and Tonkinson, R., (eds), 1982. 'Reinventing Traditional Culture: The Politics of Kastom in Island Melanesia', Mankind special issue, 13(4).

Ketan, J. 2000. 'Leadership and Political Culture', in M.A. Rynkiewich and R. Seib (eds), Politics in Papua New Guinea: Continuities, Changes and Challenges. Goroka: The Melanesia Institute.

Ketan, J. 2004. The name must not go down: Political competition and state-society relations in Mount Hagen, Papua New Guinea. Suva: Institute of Pacific Studies, University of the South Pacific.

Ketan, J. 2007. The Use and Abuse of Electoral Development Funds and their Impact on Electoral Politics and Governance in Papua New Guinea, CDI Policy Papers on Political Governance 2007/2. Canberra: Centre for Democratic Institutions, The Australian National University.

May, R.J. 1982. 'Political Style in Modern Melanesia’ in R.J. May and H. Nelson (eds), Melanesia Beyond Diversity. Canberra: Research School of Pacific Studies, The Australian National University.

May, R.J. 1997. 'Des promesses à la crise: économie politique de la Papouasie-Nouvelle Guinee'. Revue Tiers Monde, 38(149): 139-56.

May, R.J. 2003. Disorderly Democracy: Political Turbulence and Institutional Reform in Papua New Guinea, State Society and Governance in Melanesia Discussion Paper 2003/3. Canberra: Research School of Pacific and Asian Studies, The Australian National University.

May, R.J. 2004. State and Society in Papua New Guinea: the First Twenty-Five Years. Canberra: ANU E Press.

May, R.J. 2005a. District Level Governance in Papua New Guinea: Preliminary Report of a Pilot Study, State, Society and Governance in Melanesia Report. 17 June 2005. <http://rspas.anu.edu.au/papers/melanesia/conference_papers/0506_PNGDistrictGovernan ce_pilotstudy.pdf $>$ Accessed 15 May 2009.

May, R.J. 2005b. SSGM Project Report on Workshop District-Level Government in Papua New Guinea.

<http://rspas.anu.edu.au/papers/melanesia/conference_papers/0506_PNGDistrictGovernan ce_report.pdf> Accessed 15 May 2009.

May, R.J. 2006a. 'The ‘clan vote' in Papua New Guinea: Data from Angoram', The Journal of Pacific Studies, 29(1):108-129.

May, R.J. 2006b. The Public Sector Reform Process in Papua New Guinea. Public Policy in Papua New Guinea, Discussion Paper Series 2006/4. State Society and Governance in Melanesia and Papua New Guinea National Research Institute. 
May, R.J. 2008. The 2007 Election in Papua New Guinea. State Society and Governance in Melanesia, Briefing Note 7/2008. Canberra: Research School of Pacific and Asian Studies, The Australian National University.

McLeod, A. 2008. Leadership models in the Pacific. State Society and Governance in Melanesia Discussion Paper 2008/6. Canberra: Research School of Pacific and Asian Studies, The Australian National University.

Morgan, M. 2005. Cultures of Dominance: Institutional and Cultural Influences on Parliamentary Politics in Melanesia. State Society and Governance in Melanesia Discussion Paper 2005/2. Canberra: Research School of Pacific and Asian Studies, The Australian National University.

Morgan, M. and McLeod, A. 2006. 'Have we failed our neighbour?', Australian Journal of International Affairs, 60(3):412-428.

National Economic and Fiscal Commission 2003. Review of Intergovernmental Financing Arrangements: Interim Report and Proposals for a New Framework, Port Moresby: National Economic and Fiscal Commission.

National Economic and Fiscal Commission 2007. Cost! Capacity! Performance! Review of all Expenditures in 2005 by Provincial Governments. Port Moresby: National Economic and Fiscal Commission.

National Economic and Fiscal Commission 2009. Plain English Guide to the New System of Intergovernmental Financing, Port Moresby: National Economic and Fiscal Commission.

National Research Institute 2008. The Quest For Good Governance: A Survey Of Literature On The Reform Of Intergovernmental Relations In Papua New Guinea, Port Moresby: The National Research Institute.

Olsen, M. 1965. The Logic of Collective Action: Public Goods and the Theory of Groups. Cambridge: Harvard University Press.

Olson, M. 1993. 'Dictatorship, Democracy, and Development', American Political Science Review, 87(3):567:576.

Public Sector Reform Advisory Group 2006. Improved Decentralisation: Getting People Involved in Democracy, Strong Civil Society, Peace and Good Order, and Self-Reliance. Port Moresby: Government of Papua New Guinea.

Reilly, B. 2006. 'Political reform in Papua New Guinea: testing the evidence', Pacific Economic Bulletin, 21(1):187-194.

Rumsey, A. 1999. 'Social segmentation, voting and violence in Papua New Guinea', The Contemporary Pacific, 11(2):313-314.

Rynkiewich, M.A. 2000. 'Big-man Politics: Strong Leadership in a Weak State’,in M.A. Rynkiewich and R. Seib (eds), Politics in Papua New Guinea: Continuities, Changes and Challenges. Goroka: The Melanesia Institute.

Saffu, Y. 1996. 'Continuity and Change in PNG Electoral Politics', in Y. Saffu (ed.), The 1992 PNG Election: Change and Continuity in Electoral Politics. Canberra: Department of Political and Social Change, Research School of Pacific and Asian Studies, The Australian National University.

Sai'i, P. 2008. 'Management and Reporting on the District Grants', in National Development Forum On Improving The Budget Spending Process: Ensuring Transparency And Accountability At All Levels. Volume Two: Papers and Discussion. Port Moresby: Institute of National Affairs.

Standish, B. 1992. Simbu paths to power: Political change and cultural continuity in the Papua New Guinea highlands. Unpublished PhD Thesis. The Australian National University. 
Standish, B. 1996. 'Elections in Simbu: Toward gunpoint democracy', in Y. Saffu (ed.), The 1992 PNG Election: Change and Continuity in Electoral Politics. Canberra: Department of Political and Social Change, Research School of Pacific and Asian Studies, The Australian National University.

Standish, B. 2002. 'Papua New Guinea Politics: Attempting to Engineer the Future', Development Bulletin, 60:28-32.

Standish, B. 2003. 'Papua New Guinea’s most turbulent election', Catalyst, 32(2):230-248.

Standish, B. 2006. 'Limited preferential voting in Papua New Guinea: Some early lessons', Pacific Economic Bulletin, 21(1):195-211.

Standish, B. 2007. 'The dynamic of Papua New Guinea's democracy: An essay', Pacific Economic Bulletin, 22(1):135-157.

Stewart, P.J. and Strathern, A.J. 1998. 'Money, Politics, and Persons in Papua New Guinea', Social Analysis, 42(2):132-149.

Strathern, A.J. 1993. 'Violence and political change in Papua New Guinea', Bijdragen tot de Taal-, Land- en Volkenkunde, Politics, tradition and change in the Pacific, 149(4):718736.

Thomas, N. 1989. 'The Force of Ethnology: Origins and Significance of the Melanesia/Polynesia Division’, Current Anthropology, 30(1):27-41.

Whimp, K. 2009. 'If we had funding...Implementing fiscal decentralisation in Papua New Guinea.' Unpublished thesis proposal, February 2009.

Wolfers, E.P. 1982. 'Aspects of political culture and institution-building in Melanesia: Constitutional planning in Papua New Guinea and the special committee on provincial government in Solomon Islands', Pacific Studies, 6:85-108. 